\title{
Ecological Heavy Metals Risk of Saline Lake Sediments in Northwestern China
}

\author{
Dianpeng Li ${ }^{1,2}$, Jingbailun Jiang1,2, Cuixia Yan ${ }^{1,2}$, Mei Zhang, ${ }^{1,2}$ Yi Zhao ${ }^{1,2}$, Yin Xiang \\ Wenqi Ma ${ }^{1,2}$, Hongtao Jia ${ }^{1,2 *}$, Xiaoning Zhao ${ }^{3-5}$ \\ ${ }^{1}$ College of Grassland and Environmental Sciences, Xinjiang Agricultural University, \\ Urumqi, Xinjiang, China \\ ${ }^{2}$ Xinjiang Key Laboratory of Soil and Plant Ecological Processes, Urumqi, Xinjiang, China \\ ${ }^{3}$ State Key Laboratory of Desert and Oasis Ecology, Xinjiang Institute of Ecology and Geography, \\ Chinese Academy of Sciences, Urumqi, Xinjiang, China \\ ${ }^{4}$ Aksu National Station of Observation and Research for Oasis Agro-Ecosystem, \\ Aksu, Xinjiang, China \\ ${ }^{5}$ University of Chinese Academy of Sciences, Beijing, China
}

Received: 13 July 2019

Accepted: 8 September 2019

\begin{abstract}
Lake sediment as a potential sink and source of contaminants, it is still relatively less known about than the ecological heavy metals risk in an arid region saline lake. The goal of this study aimed to reveal concentrations of $\mathrm{Cr}, \mathrm{Ni}, \mathrm{Cu}, \mathrm{Zn}, \mathrm{As}, \mathrm{Cd}$ and $\mathrm{Pb}$ in saline lake sediments, and to evaluate its pollution status, potential ecological risks and sources for sediments in the study area. Here we analyzed 13, 15 and 8 sediment samples from Ebinur Lake, Barkol Lake and Dabancheng Saline Lake, respectively. The mean concentrations of $\mathrm{Cr}\left(74.55 \mathrm{mg} \mathrm{kg}{ }^{-1}\right), \mathrm{Cu}\left(27.75 \mathrm{mg} \mathrm{kg}^{-1}\right), \mathrm{Zn}\left(73.00 \mathrm{mg} \mathrm{kg}^{-1}\right)$, As (37.65 mg kg $\mathrm{mg}^{-1}$ ), and $\mathrm{Cd}\left(0.31 \mathrm{mg} \mathrm{kg}^{-1}\right)$ were higher than the background values of the Xinjiang, and the mean enrichment factor $(E F)$ and geo-accumulation index $\left(I_{\text {geo }}\right)$ showed that As $(E F=7.44$, $\left.I_{\text {geo }}=1.35\right)$ and $\mathrm{Cd}\left(E F=11.09, I_{\text {geo }}=0.50\right)$ in saline lake sediments were moderate and partially seriously contaminated, while $\mathrm{Cr}, \mathrm{Zn}$ and $\mathrm{Cu}$ caused moderate pollution. The potential ecological $(R I)$ seven heavy metals risk assessment degree decreased in the following sequence: $\mathrm{Cd}$ (78.77) $>\mathrm{As}(32.22)>\mathrm{Cu}$ (5.22) $>\mathrm{Ni}$ (4.28) $>\mathrm{Pb}(3.27)>\mathrm{Cr}(3.21)>\mathrm{Zn}$ (1.07), and the $R I$ for $\mathrm{Cd}$ exhibited moderate to considerable risk. The As and Cd were the major risk factors among the seven metals. Correlation analysis, principal component analysis and hierarchical cluster analysis deduced that $\mathrm{Cu}, \mathrm{Ni}$, and $\mathrm{Zn}$ originate mainly from a geological background, while $\mathrm{As}, \mathrm{Cd}$ and $\mathrm{Cr}$ were mainly from anthropogenic sources. Anthropogenic activities lead to heavy metals enrichment in sediments, while As and Cd are the primary contaminants in saline lake sediments in northwestern China.
\end{abstract}

Keywords: heavy metals, risk assessment, saline lake, sediment pollution, arid region

*e-mail: jht@xjau.edu.cn 


\section{Introduction}

There are numerous lakes in Xinjiang Uygur Autonomous Region, China, with a total area of 6236 $\mathrm{km}^{2}$ [1]. Lakes play a crucial role in sustaining ecology, water supply, climate regulation, and restricting economic activity of society in arid areas [2]. Sediments are a crucial part of the lake ecosystem as they receive every year large number of pollutants from different sources [3], which is one of the most vital components of a lake in a biogeochemical cycle $[4,5]$. Sediment is a potential sink and source of contaminants when the environmental conditions were changing [5-7]. Due to the high flocculation and adsorption processes, lake sediments could hold about $90 \%$ of metals in the lake ecosystem, indicating that they were highly susceptible to pollution [8,9]. Moreover, sediment also serves as a potential secondary source of heavy metals that might be released back into water columns when environmental and climate conditions were changing, then transmitted along the food chain and finally endangered public health [10].

Sediment quality assessment is an essential part of the environmental quality assessment of an aquatic ecosystem, and determining the ecological risks caused by heavy metals is the most important precondition of aquatic ecological environmental protection, human health, and sustainability [11]. Much research has reported the sediment quality status of lakes, rivers, reservoirs and groundwater in China, such as the freshwater Poyang Lake [12], eutrophic plateau Erhai Lake [11], Taihu Lake [13, 14], deep mountain Sayram Lake [15], the reservoirs of Tongjiqiao Reservoir [16], Three Gorges Reservoir [17] and groundwater [18, 19] they were all contaminated with heavy metals to varying degrees, anthropogenic contaminate having become a serious public environmental problem in some lakes. With the rapid developing industrial operations and fast urban expansion since 1970s, soil, water and sediment polluted by heavy metals has been both serious and widespread in many provinces [20-22]. For the past few years, researchers have studied the contaminate status of trace elements in arid soil [23], water [24] and sediments [25], as well as ecological heavy metal risks. Mamat et al. [26] studied the contamination statuses of zinc $(\mathrm{Zn})$, lead $(\mathrm{Pb})$, copper $(\mathrm{Cu})$, mercury $(\mathrm{Hg})$, nickel $(\mathrm{Ni})$, arsenic (As), cadmium $(\mathrm{Cd})$ and chromium $(\mathrm{Cr})$ in Bosten Lake in northwest China. The average values of these heavy metals were higher than the background values of the research area, and found that levels of $\mathrm{Cd}, \mathrm{Pb}, \mathrm{Hg}$, and $\mathrm{Zn}$ were primarily influenced by human activities. Wang et al. [23] assessed the pollution statuses of heavy metals in an industrial city (Dushanzi District), and the average contents of heavy metals were all higher than the background values of soils in Xinjiang and were primarily influenced by industrial activities. Zhou et al. [19] researched As concentrations greater than $10 \mathrm{mg} \mathrm{L}^{-1}$ found in $12 \%$ of analyzed groundwaters, and this region has become a hotspot to face with multi-metal problems - especially As after 1960. However, to our knowledge there has been little research regarding sediment pollution of a saline lake.

Xinjiang has more than 120 lakes and rivers that cover $7.7 \%\left(6236 \mathrm{~km}^{2}\right)$ of the total lake area of China (81 $414.6 \mathrm{~km}^{2}$ ), and is one of the most important lakes distribution ranges, and half lakes were saline lake [27]. After the development of the western regions of China, the state strongly supported the economic development of the oases cities - especially what China has proposed and actively advanced as the Belt and Road. The northwestern five provinces, especially Xinjiang, is one of the country's most important new economic development zones and is the main route for ensuring the participation of northwestern China in the global economy. Numerous industries such as mining, oil and gas exploitation, petroleum chemical, coal and agriculture, have majorly contributed to the economic development of Xinjiang; however, they have extensively impacted the ecological environment of the region. Limited studies are available regarding pollution in a saline lake. Therefore, comprehensive domestic studies regarding this are required in order to deepen our understanding of the contamination status and the ecological risk of heavy metals in Xinjiang saline lakes. Here, typical saline lakes such as Ebinur, Barkol and Dabancheng Saline were selected as the research area and sampled basic properties, and heavy metals concentrations of $\mathrm{Cr}, \mathrm{Ni}, \mathrm{Cu}, \mathrm{Zn}$, $\mathrm{As}, \mathrm{Cd}$, and $\mathrm{Pb}$ in sediments. The specific objectives of this study were to: (1) investigate the heavy metals concentrations in the saline lake sediments; (2) assess the risk associated with the seven heavy metals; and (3) determine pollution sources. This study aims to provide worthwhile information regarding the pollution levels and any possible sources of seven elements. The results of the present study can provide reference information to facilitate saline lake resource development and management activities in regions with industries and agriculture that are contaminated with these elements.

\section{Material and Methods}

\section{Study Area}

Xinjiang Uygur Autonomous Region is the biggest province in China, which covers 1.66 million $\mathrm{km}^{2}$ $\left(73^{\circ} 40^{\prime} \mathrm{E}-96^{\circ} 23^{\prime} \mathrm{E}, \quad 34^{\circ} 25^{\prime} \mathrm{N}-49^{\circ} 10^{\prime} \mathrm{N}\right)$, representative of the arid and semi-arid region. Lakes in Xinjiang were distributed in uneven and various types, such as a freshwater lake (Boston Lake and Sayram Lake), saltwater lake (Ulungur Lake), saline lake (Ebinur Lake, Barkol Lake, Dabancheng Saline Lake, etc.), and playa lake (Lop Nur Saline, Ayding Lake). All the closed basins develop tail-end-lake (or saline lake) in arid regions. In this study, we selected three typical sodium sulfate saline lakes (Ebinur, Barkol and Dabancheng) along the north slopes of the Tianshan 
Mountains as the research objectives. They are located in western, middle and eastern Tianshan Mountains, respectively. The basic properties of saline lakes were shown in Table 1. So far, approximately143 383, 102 400 and 41258 people live in Jinghe County, Barkol County and Dabancheng District, respectively. With increasing human disturbance and economic growth the saline lake areas were decreased rapidly. The saline lake ecosystem may be at risk.

\section{Sediment Sampling and Analyses}

Thirty-six surface $(0-20 \mathrm{~cm})$ sediment samples were collected by gravity corer around the lakes (Fig. 1) in October 2018. Ebinur, Barkol, and Dabancheng lakes were collected 13 (A01-A13), 15 (B01-B15), and 8 (D01-D08) samples, respectively. Fig. 1 shows the research area and sampling sites included in the inlet of the saline lake. Sediment locations were selected based on water body shape characteristic to represent the entire area of the lakebed. In each site we used a plastic spatula to collect the 0-20 cm lakebed sediment, and put the sample into collection bags. All samples weighted more than 500 g. During the sample processing, the site number, date, longitude and latitude of each sample were recorded on the sampling bag. Then all sediments were taken back to the laboratory and air dried, then we picked up the stone and roots and pushed through a 25 and 100 mesh nylon sieve $(1 \mathrm{~mm}$ and $0.25 \mathrm{~mm})$ and preparation for analysis.

The concentrations of heavy metals in sediment were measured following the protocols [28, 29]. Briefly, $250 \mathrm{mg}$ of sample was weighed and placed into Teflon beaker digestion with $\mathrm{HNO}_{3}(5.0 \mathrm{~mL})$-HF $(10 \mathrm{~mL})$ $\mathrm{HClO}_{4}(2.0 \mathrm{~mL})$-aqua regia $\left(\mathrm{HCl} / \mathrm{HNO}_{3} 3: 1,8 \mathrm{~mL}\right)$, then an Agilent $7700 \times$ inductively coupled plasma mass spectrometer (ICP-MS) was used to measure the $\mathrm{Cd}, \mathrm{Pb}$, $\mathrm{Ni}$ and As content; and concentrations of the elements ( $\mathrm{Zn}, \mathrm{Cu}, \mathrm{Mn}, \mathrm{Cr}$ ) were determined using inductively coupled plasma optical emission spectroscopy (ICPOES). In order to guarantee the quality of the analysis, analytical blanks, duplicate samples, and standards were implemented and GBW07408 (GSS-8, from Institute of geophysical and geochemical exploration, Chinese academy of geological sciences) were used to verify the accuracy and precision, and percentage recoveries of the selected heavy metals reference metals ranged from $95 \%$ to $105 \%$. The detection limits of heavy metals were $70 \mathrm{mg} \mathrm{kg}^{-1}$ for $\mathrm{Cr}, 31.7 \mathrm{mg} \mathrm{kg}^{-1}$ for $\mathrm{Ni}, 23.9 \mathrm{mg} \mathrm{kg}^{-1}$ for $\mathrm{Cu}, 70 \mathrm{mg} \mathrm{kg}^{-1}$ for $\mathrm{Zn}, 12.3 \mathrm{mg} \mathrm{kg}^{-1}$ for As, $0.13 \mathrm{mg} \mathrm{kg}^{-1}$ for $\mathrm{Cd}$, and $20 \mathrm{mg} \mathrm{kg}^{-1}$ for $\mathrm{Pb}$. In addition, each sample triplicate analysis also indicated good precision as the mean relative standard deviation was less than $5 \%$.

Sediment total carbon (TC) and total nitrogen (TN) were measured with the elemental analyzer (Euro EA3000-Single, EuroVector, Milan, Italy) [30]. Total phosphorus (TP) concentrations were measured by $\mathrm{NaOH}$ alkali fusion and the molybdenum-antimony anti-spectrophotometric methods [31]. Sediment $\mathrm{pH}$ and electrical conductivity (EC) were determined by standard procedures described by Bao [32] using sediment extract solutions (sediment: water $=1: 5$ ). The $\mathrm{pH}$ was measured using a glass electrode $\mathrm{pH}$ meter PHS-3C instrument and EC was measured using a conductivity DDS-307 meter [32].

\section{Assessment of Sediment Contamination}

\section{Enrichment Factor}

We used enrichment factor $(E F)$ to quantitatively assess the levels of heavy metal pollution in a saline lake [16]. The heavy metal concentration data should be

Table 1. Basic information of saline lake.

\begin{tabular}{|c|c|c|c|}
\hline Saline lake & Ebinur & Dabancheng & Barkol \\
\hline Location & $\begin{array}{l}43.63^{\circ}-45.87^{\circ} \mathrm{N} \\
79.88^{\circ}-85.03^{\circ} \mathrm{E}\end{array}$ & $\begin{array}{l}43.35^{\circ}-43.41^{\circ} \mathrm{N} \\
88.12^{\circ}-88.20^{\circ} \mathrm{E}\end{array}$ & $\begin{array}{l}43.60^{\circ}-43.73^{\circ} \mathrm{N} \\
92.73^{\circ}-92.95^{\circ} \mathrm{E}\end{array}$ \\
\hline Area $/ \mathrm{km}^{2}$ & 522 & 10 & 60 \\
\hline Altitude/m & 189 & 1071 & 1585 \\
\hline Saline type & Sodium sulfate & Sodium sulfate & Sodium sulfate \\
\hline $\mathrm{MAT} /{ }^{\circ} \mathrm{C}^{*}$ & 7.8 & 5.1 & 1.1 \\
\hline $\mathrm{MAP} / \mathrm{mm}^{*}$ & 91 & 261 & 210 \\
\hline $\mathrm{EVA} / \mathrm{mm}^{*}$ & 1500 & 2074 & 2250 \\
\hline $\mathrm{pH}$ value & 8.49 & 8.38 & 7.6 \\
\hline Salinity/g L ${ }^{2}$ & 112.4 & 68.1 & 204.76 \\
\hline Age/Ka B.P. & $21-8.2$ & $21-8.2$ & $47-26$ \\
\hline
\end{tabular}

Notes: MAT, MAP and EVA represent mean annual temperatures, mean annual precipitation and evapotranspiration, respectively.

*Mean annual temperatures, mean annual precipitation data were from 1990 to 2010 (http://data.cma.cn/site/index.html). 

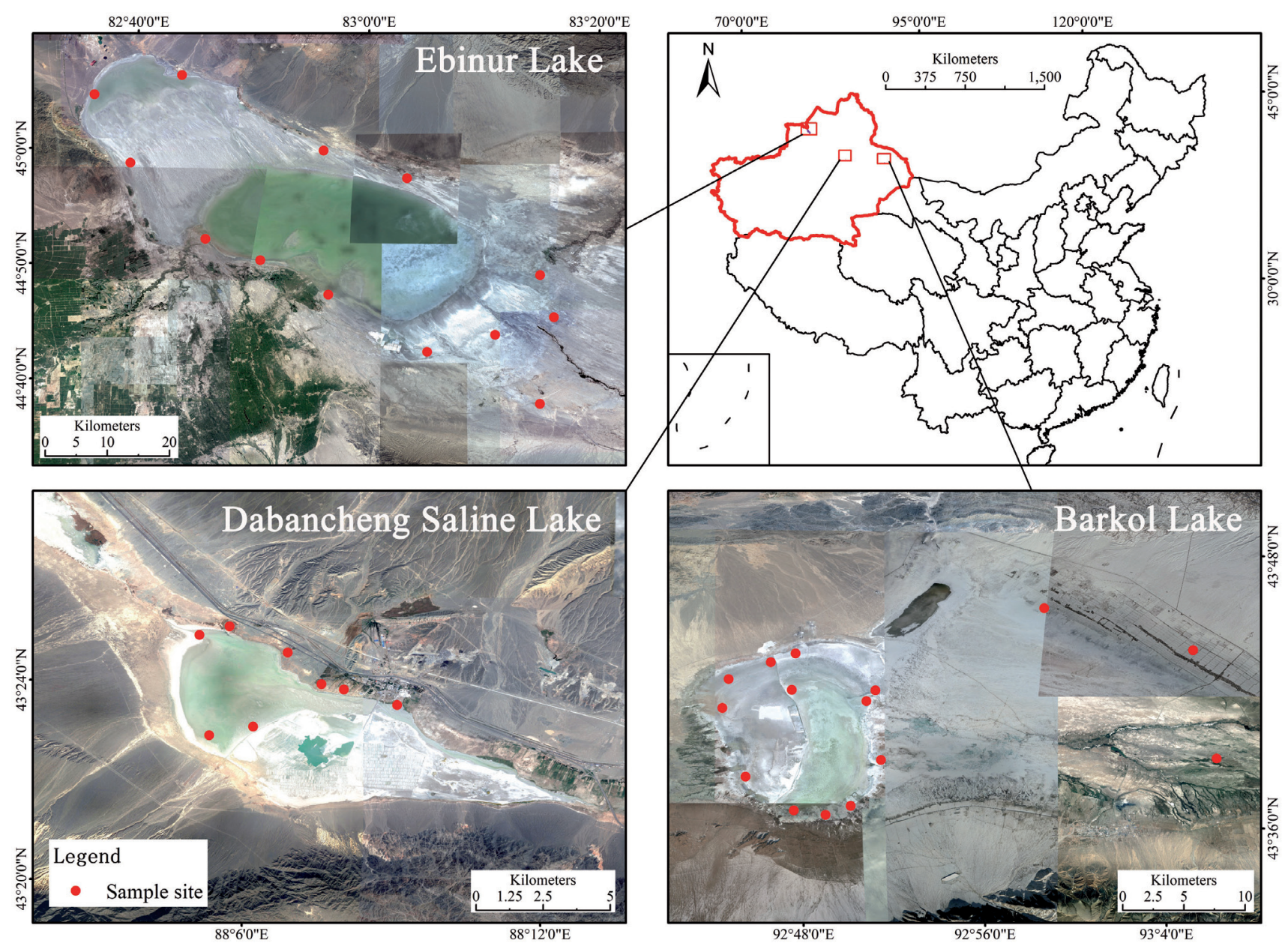

Fig. 1. Location of study area and sampling sites. The red sits represent the sample sites.

normalized by a conservative element in order to reduce the impact of the particle grain size. The elements of manganese $(\mathrm{Mn})$, aluminum (Al), iron (Fe), and calcium (Ca) were common as the reference elements, Mn primary comes from natural lithogenic and is already recognized as a standardized element [33]. EF is calculated as displayed below [34]:

$$
\mathrm{EF}=\left(C_{i} / C_{M_{n}}\right)_{\text {samples }} /\left(B_{i} / B_{M_{n}}\right)_{\text {baseline }}
$$

...where $E F$ is the enrichment level of a certain element, $C_{i}$ is the concentration of $i$ heavy metals in the sediment, $C_{M_{n}}$ is the concentration of the reference element, $B_{i}$ is the background value of the north Xinjiang soil and $B_{M_{M}}$ is the background concentration of the reference element of the soil in the same region [35]. The values of $\mathrm{Cr}, \mathrm{Ni}, \mathrm{Cu}, \mathrm{Zn}, \mathrm{As}, \mathrm{Cd}$ and $\mathrm{Pb}$ were 49.30, 26.60, 26.70, $68.80,11.20,0.12$, and $19.40 \mathrm{mg} \mathrm{kg}^{-1}$, respectively. The enrichment factor corresponding to pollution level were referred to by Liu et al. [36].

\section{Geo-accumulation Index}

The geo-accumulation index $\left(I_{\text {geo }}\right)$ enables evaluation of heavy metal pollution in sediment based on the rate of current concentrations/pre-industrial levels [37]. The $I_{g e o}$ is defined by the following equation:

$$
I_{\text {geo }}=\log _{2}\left[C_{n} /\left(K \times B_{i}\right)\right]
$$

...where $C_{n}$ is the measured content of heavy metal and $B_{i}$ is the geochemical background value of a particular heavy metal. In this study, we chose the average values of Jounggar region, Xinjiang shale as the background reference values, because the Ebinur Lake, Barkol Saline Lake and Dabancheng Saline Lake all locked in Jounggar basin, and the concentrations of $\mathrm{Cr}, \mathrm{Ni}$, $\mathrm{Cu}, \mathrm{Zn}, \mathrm{As}, \mathrm{Cd}$ and $\mathrm{Pb}$ were 58.14, 26.15, 30.27, 71.41, 9.02, 0.14 and $15.44 \mathrm{mg} \mathrm{kg}^{-1}$, respectively [38]. $K$ is the background matrix correction factor $(K=1.5)$ [39]. $I_{\text {geo }}$ provides a classification system for the degree of pollution (Table 2) [40].

\section{Potential Ecological Risk Index}

The potential ecological risk index $(R I)$ was introduced to assess the degree of contamination of trace metals in sediments [41]. The equations for $R I$ are as follows: 
Table 2. Evaluation criteria of Geo-accumulation index $\left(I_{\text {geo }}\right)$.

\begin{tabular}{|c|c|}
\hline$I_{g e o}$ & Pollution level \\
\hline$<0$ & Unpolluted \\
\hline $0-1$ & Unpolluted to moderately polluted \\
\hline $1-2$ & Moderately polluted \\
\hline $2-3$ & Moderately to strongly polluted \\
\hline $3-4$ & Strongly polluted \\
\hline $4-5$ & Strongly to very strongly polluted \\
\hline$\geq 5$ & Very strongly polluted \\
\hline
\end{tabular}

Notes: the data very cited from Förstner (1990) and Bhuiyan (2010).

$$
\begin{aligned}
& C_{f}^{i}=C_{s}^{i} / C_{n}^{i} \\
& E_{r}^{i}=T_{r}^{i} \times C_{f}^{i} \\
& R I=\sum_{i=1}^{n} E_{r}^{i}
\end{aligned}
$$

...where $C_{s}^{i}$ is the content of the element in samples, $C_{n}{ }^{i}$ is the background value of the element, $C_{f}^{i}$ is the single element pollution factor, $E_{r}{ }^{i}$ is the $R I$ index of an individual element, and $T_{r}^{i}$ is the biological toxicity factor of an individual element. Based on the references, the $\mathrm{t}$ biological toxicity factor of $\mathrm{Pb}, \mathrm{Cu}, \mathrm{Ni}, \mathrm{Cd}, \mathrm{As}$, $\mathrm{Cr}$ and $\mathrm{Zn}$ in this study were 5, 5, 5, 30, 10, 2, and 1, respectively [41]. $R I$ is the comprehensive potential ecological risk index, which is the sum of $E_{r}{ }_{r}$. Table 3 shows the factor standard of different levels. Hakanson [41] defined five categories of $E_{r}^{i}$ (low risk, $E_{r}^{i}<40$; moderate risk, $40 \leq E^{i}<80$; considerable risk, $80 \leq E^{i}<160$; high risk, $160 \leq E_{r}^{i}<320$; very high risk, $\left.E_{r}^{i} \geq 320\right)$ and four categories of $R I$ (low risk, $R I<150$; moderate risk, $150 \leq R I<300$; considerable risk, $300 \leq R I<600$; very high risk, $R I \geq 600)$.

\section{Data Analysis}

In order to obtain the characteristics, relationships, associations, and heavy metal behavior in sediment of Ebinur, Barkol and Dabancheng lakes, correlation analysis, principal component analysis (PCA), and cluster analysis were carried out. In this study, the average, extreme value, and standard error were used. Pearson's correlation analysis was used to test the relationships among the heavy metals $(p<0.05)$. PCA was applied to identify the hypothetical source of heavy metals based on the concentrations of all heavy metals with varimax rotation to assist the identification and analysis of sources of trace elementals in sediments from a saline lake [42]. The purpose of cluster analysis is to demonstrate the cluster relationship between the seven heavy metals [43]. Data calculation, PCA, CA, and Pearson's correlation analyses were performed with SPSS 18 for Windows (SPSS, Inc., USA).

\section{Results and Discussions}

\section{Properties and Heavy Metals of Surface Sediments}

The average contents of $\mathrm{Cr}, \mathrm{Ni}, \mathrm{Cu}, \mathrm{Zn}, \mathrm{As}, \mathrm{Cd}$, and $\mathrm{Pb}$ were $74.55,22.33,27.75,73.00,37.65,0.31$ and $12.78 \mathrm{mg} \mathrm{kg}^{-1}$, respectively (Fig. 2 and Table 3). The mean concentrations of $\mathrm{Cr}, \mathrm{Cu}, \mathrm{Zn}$, As and $\mathrm{Cd}$ exceed

Table 3. Descriptive statistics physiochemical properties and heavy metals of the sediments from saline lake $(n=36)$.

\begin{tabular}{|c|c|c|c|c|}
\hline Index & Standard deviation & Variable coefficient (\%) & Kurtosis & Skewness \\
\hline $\mathrm{pH}$ & 0.26 & 2.93 & 0.90 & 0.64 \\
\hline $\mathrm{EC}\left(\mathrm{dS} \mathrm{m}^{-1}\right)$ & 31.25 & 67.96 & 0.47 & 0.65 \\
\hline $\mathrm{TP}\left(\mathrm{g} \mathrm{kg}^{-1}\right)$ & 0.13 & 28.57 & 2.05 & 1.73 \\
\hline $\mathrm{TN}(\%)$ & 0.21 & 117.75 & 2.19 & 1.51 \\
\hline $\mathrm{TC}(\%)$ & 1.93 & 63.01 & 2.33 & -0.53 \\
\hline $\mathrm{Cr}\left(\mathrm{mg} \mathrm{kg}^{-1}\right)$ & 27.96 & 37.50 & -0.45 & 0.54 \\
\hline $\mathrm{Ni}\left(\mathrm{mg} \mathrm{kg}^{-1}\right)$ & 8.21 & 36.74 & -0.49 & 0.43 \\
\hline $\mathrm{Cu}\left(\mathrm{mg} \mathrm{kg}^{-1}\right)$ & 8.95 & 32.24 & -0.38 & -0.16 \\
\hline $\mathrm{Zn}\left(\mathrm{mg} \mathrm{kg}^{-1}\right)$ & 13.46 & 18.44 & -0.73 & 2.73 \\
\hline $\mathrm{As}\left(\mathrm{mg} \mathrm{kg}^{-1}\right)$ & 19.54 & 51.88 & 8.91 & 2.31 \\
\hline $\mathrm{Cd}\left(\mathrm{mg} \mathrm{kg}^{-1}\right)$ & 0.09 & 28.53 & 9.36 & 0.38 \\
\hline $\mathrm{Pb}\left(\mathrm{mg} \mathrm{kg}^{-1}\right)$ & 4.88 & 38.19 & -0.88 & \\
\hline
\end{tabular}

Notes: EC, TP, TN and TC were represented electric conductivity, total phosphor, total nitrogen and total carbon. 

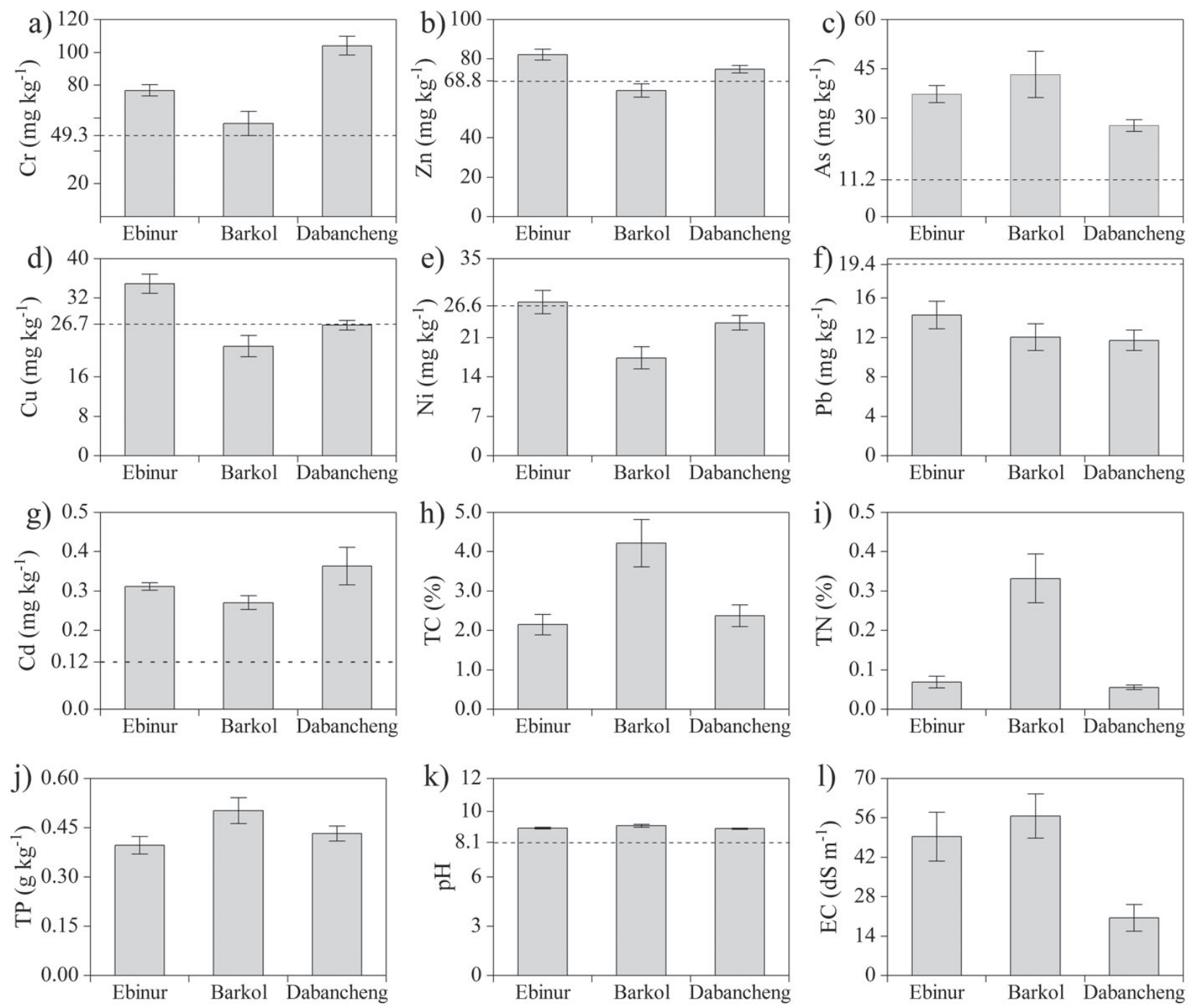

Fig. 2. Physiochemical properties and heavy metals of the sediments from saline lake (mean $\pm \mathrm{SD}$ ). The broken line represent background value of the Xinjiang soil.

background values, with As and Cd reaching more than twice the time of their responding background values. The heavy metals $\mathrm{Cu}, \mathrm{Zn}$, and $\mathrm{Cd}(32.24 \%, 18.44 \%$ and $28.53 \%)$ had moderate variability $(15 \%<\mathrm{CVs}<36 \%)$, while $\mathrm{Cr}, \mathrm{Ni}, \mathrm{As}$ and $\mathrm{Pb}(37.50 \%, 36.74 \%, 51.88 \%$ and $38.19 \%)$ had high variability $(\mathrm{CVs}>36 \%)$ and the CVs of As were higher than other elements. The Kurtosis values of heavy metal contents ranged from -0.88 to 9.36, and the skewness of various elements followed a decreasing trend of $\mathrm{As}>\mathrm{Cd}>\mathrm{Ni}>\mathrm{Cu}>\mathrm{Pb}>\mathrm{Zn}>\mathrm{Cr}$, while the skewness of $\mathrm{As}$ and $\mathrm{Cd}$ were quite a bit higher. According to the high $\mathrm{CV}$ of $\mathrm{As}$ and $\mathrm{Pb}$, and positively skewed frequency distribution, indicating that common presence of a point source contamination [44]. The $\mathrm{pH}$ of surface sediment ranged from 8.55 to 9.72 with an average of 9.03 - higher than the soil background value $(\mathrm{pH}=8.1)$. Additionally, the EC, TP, $\mathrm{TN}$ and TC were $45.99 \mathrm{dS} \mathrm{m}{ }^{-1}, 0.45 \mathrm{~g} \mathrm{~kg}^{-1}, 0.18 \%$ and $3.06 \%$, respectively.

\section{Risk Assessment}

The degree of enrichment of heavy metals, in descending order, was: $\mathrm{As}>\mathrm{Cd}>\mathrm{Cr}>\mathrm{Cu}>\mathrm{Zn}>\mathrm{Ni}>\mathrm{Pb}$ (Fig. 3). The mean $E F$ values of $\mathrm{Ni}, \mathrm{Cu}$, and $\mathrm{Pb}$ were $2.39,2.98$, and 1.90 , respectively, belonging to minor enrichment. The EF mean values of $\mathrm{Cr}$ and $\mathrm{Zn}$ were 4.09 and 3.10, which reached moderate enrichment. In particular, the $\mathrm{As}$ and $\mathrm{Cd}$ were 11.09 and 7.44 belonging to moderate severe enrichment and severe enrichment, and the maximum value of As was 43.99, very severe enrichment, which were obviously similar to those of the heavy metals in the sediments of water body, reservoir and lakes in other study areas. In the urban river of Bangladesh, the EFs of heavy metals in the sediments ranged from 1.3 to 5.9 , which belonged to moderate enrichment [45]. The EF value of $\mathrm{Cr}, \mathrm{Zn}$, $\mathrm{Pb}$ and $\mathrm{Cu}$ in the sediments of Lake Pamovtis were considered moderate to extremely severe enrichment 


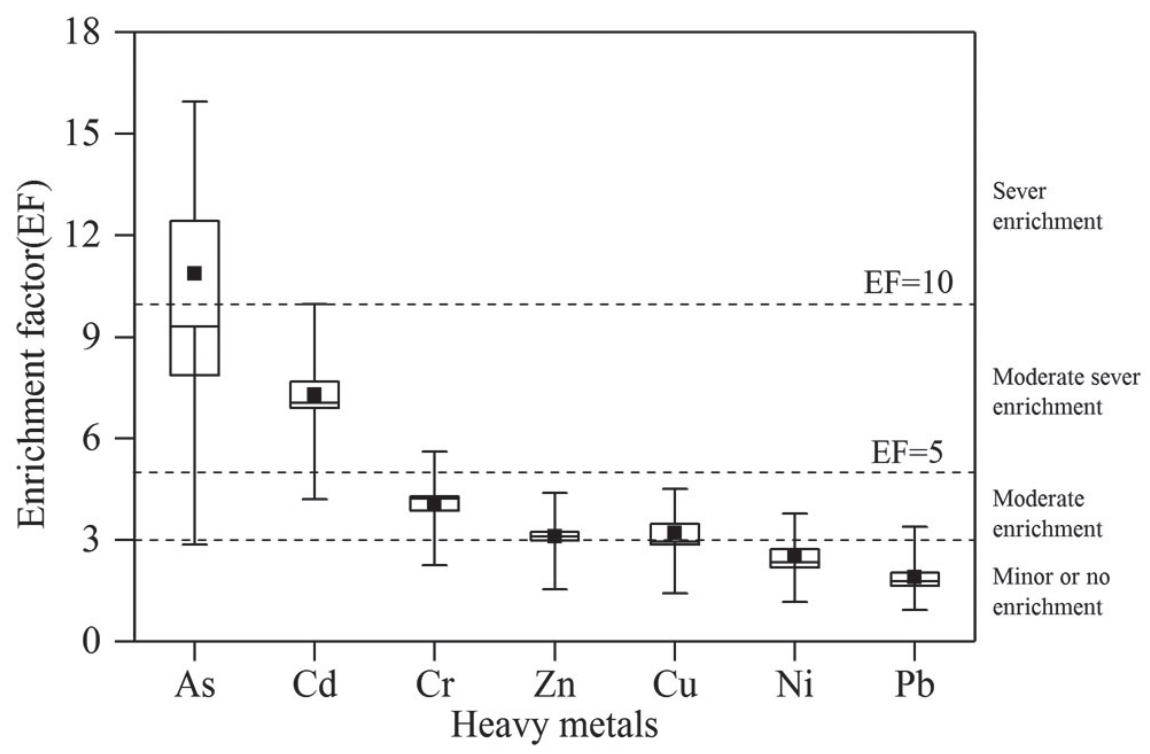

Fig. 3. Enrichment factor $(E F)$ of heavy metals in surface sediment from saline lake. In box plots, center values are medians, solid lines indicate variability outside the upper and lower quartiles, and Solid Square represents mean value.

[46]. The heavy metals ranges of $\mathrm{Cu}, \mathrm{Zn}, \mathrm{Pb}, \mathrm{Cd}$ and $\mathrm{Hg}$ from 1.4 to 7.3 in Erhai Lake, which were determined as minor to moderately severe enrichment [11], indicating that more factitious metals has been imported into the saline lake during industrial expansion.

As shown in Fig. 4, the $I_{g e o}$ of metals at each site and the entire lake average was calculated. Among the studied metals, the $I_{\text {geo }}$ value diminishing order of $\mathrm{As}>\mathrm{Cd}>\mathrm{Cr}>\mathrm{Zn}>\mathrm{Cu}>\mathrm{Ni}>\mathrm{Pb}$. Among these sites, the range of $I_{g e o}$ value for As range from 0.63 to 3.10, and the mean value was 1.35 , indicating moderately polluted statues of sediment, whereas the $I_{\text {geo }}$ value for $\mathrm{Cd}(-0.15$ to 1.72). Besides, the $I_{g e o}$ values of $\mathrm{Cr}, \mathrm{Ni}, \mathrm{Cu}, \mathrm{Zn}$, and $\mathrm{Pb}$ were lower than zero without pollution. The result for heavy metal concentration in the sediment of the saline lake according to the $R I$ are shown in Fig. 5. The pollution degree of seven heavy metals decreased in the following sequence: $\mathrm{Cd}>\mathrm{As}>\mathrm{Cu}>\mathrm{Ni}>\mathrm{Pb}>\mathrm{Cr}>\mathrm{Zn}$. Compared with other metals, the $R I$ for $\mathrm{Cd}$ exhibited moderate to considerable risk. In particular, the highest $R I$ of $\mathrm{Cd}(=172.54)$ in site D08 posed high risk, D06 (105.13) and B01 (110.01) were posed at considerable risk. $R I$ of As in sites B14 (103.54) and B15 (91.05) were classified as considerable risk, but of As for most saline lake sample sites were classified as low risk. A total of $4(11.1 \%)$ sites exhibited moderate risk, and approximately $89.9 \%$ (32 sites) of the site presented low risk. Compared with other rivers, marine environments and lakes, the values of $I_{g e o}$, and $R I$ of $\mathrm{Cd}, \mathrm{Cr}, \mathrm{Zn}, \mathrm{Cu}$, $\mathrm{Ni}$ and $\mathrm{Pb}$ in sediments of saline lake were relatively low, and the contaminate levels were also low, such as Dianchi in China [47], and marine sediments from New Zealand [48]. Nevertheless, As was considered moderately to strongly polluted in most sediment samples of three saline lakes. Our results also indicated that the concentrations of As and the contaminate status in the sediments of saline lakes were higher than in the freshwater lake (Bosten Lake), Northwest China [26], and sediments of the Yangtze River estuary [33]. In brief, our research found the pollution status of $\mathrm{Zn}, \mathrm{Cu}$, $\mathrm{Cr}, \mathrm{Ni}$, and $\mathrm{Pb}$ in three saline lakes were on a relatively low level, though the pollution of $\mathrm{As}$ and $\mathrm{Cd}$ were significantly higher than other heavy metals.

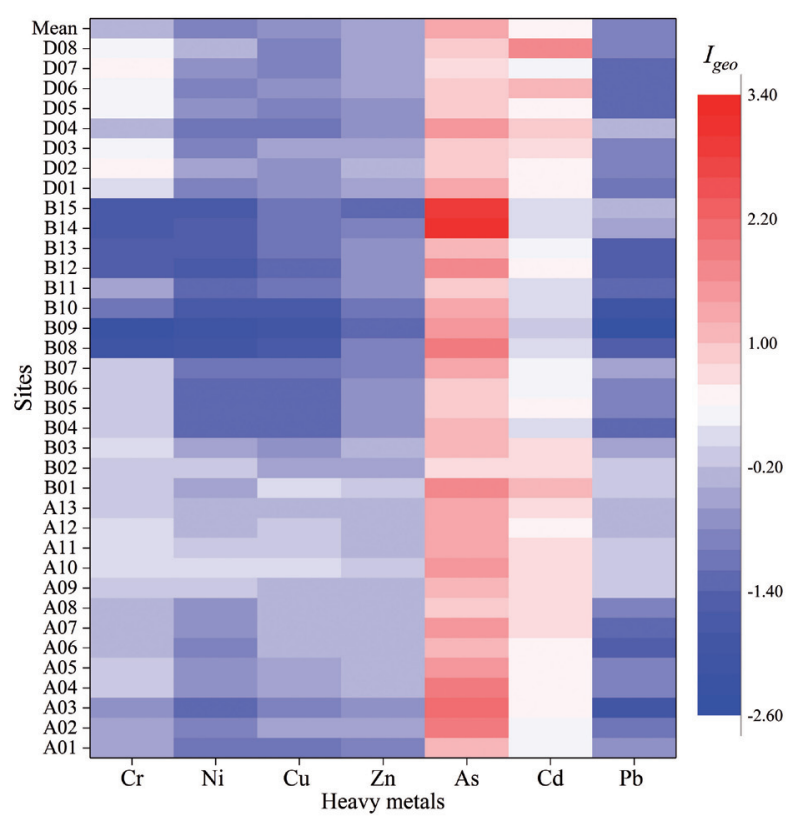

Fig. 4. Geo-accumulation index of heavy metals in the surface sediment of the saline lake. Ebinur Lake, Barkol Lake, and Dabancheng Saline Lake were A01-A13, B01-B15, and D01-D08, respectively. The color of the red becomes darker as the sediment heavy metals pollution ranks get higher, on the contrary the blue becomes darker as the saline lake sediment without heavy metals contaminate. 


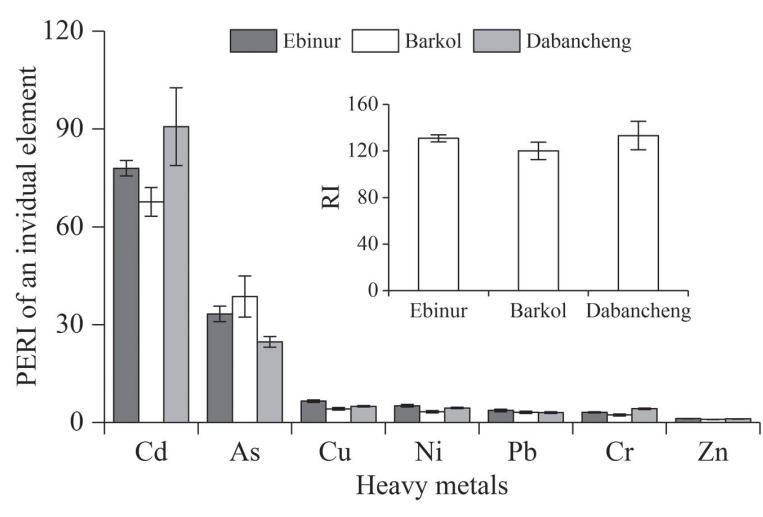

Fig. 5. Potential ecological risk index $(R I)$ of heavy metals in the surface sediments of the saline lake (mean $\pm \mathrm{SD})$.

\section{Identification of Sources of Heavy Metals in Saline Lake Sediments}

\section{Correlation Analysis}

As shown in Table 4, the $\mathrm{pH}$ was negatively correlated with any heavy metals expect for As. EC was negatively correlated with $\mathrm{Cr}, \mathrm{Ni}$, and $\mathrm{Cd}$, and there was no correlation among TP and heavy metals. TN was negatively correlated with $\mathrm{Cr}$ and $\mathrm{Zn}$, TC was negatively correlated with $\mathrm{Cr}, \mathrm{Ni}, \mathrm{Cu}, \mathrm{Zn}$ and $\mathrm{Cd}$, positively correlated with As. There was a significantly positive correlation between 14 elemental pairs at the 0.01 level, and two elemental pairs, Zn-As $(r=-0.338)$ and $\mathrm{Cd}-\mathrm{Pb}(r=0.344)$, had a significant correlation at the 0.05 level. Otherwise, $\mathrm{Cu}, \mathrm{Zn}, \mathrm{Ni}$ and $\mathrm{Pb}$ were positively correlated among each other. There was a significant correlation among $\mathrm{Cu}, \mathrm{Zn}, \mathrm{Ni}$ and $\mathrm{Cr}, \mathrm{Cd}$, and $\mathrm{Pb}$, while significant negative correlations were

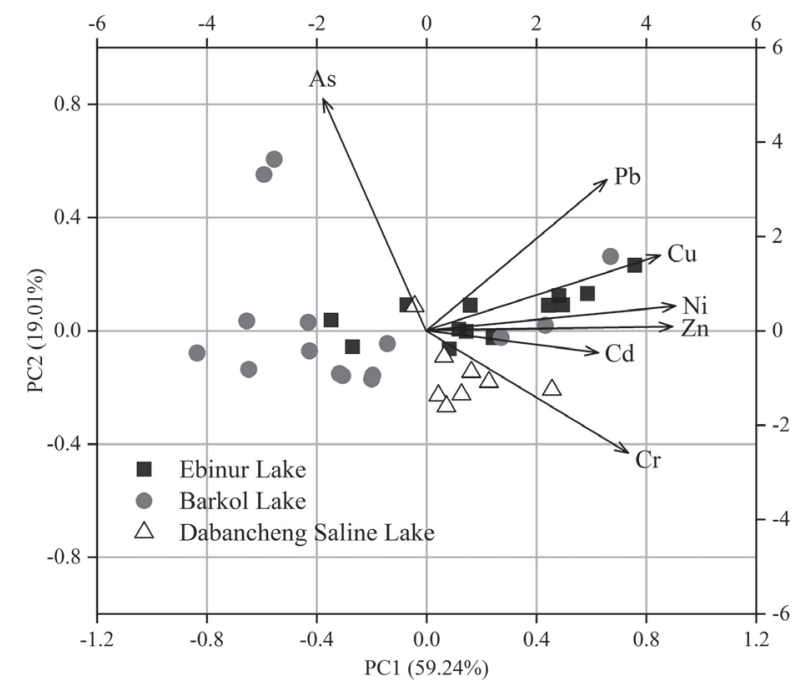

Fig. 6. Principal component analysis of heavy elements in surface sediment from saline lake.

found between $\mathrm{Cr}, \mathrm{Zn}$ and As, and significant positive correlations with TC.

\section{Principal Component Analysis (PCA)}

The PCA reduces the number of variables to two components (PCs). $\mathrm{Pb}, \mathrm{Cu}, \mathrm{Ni}, \mathrm{Zn}, \mathrm{Cd}$, and $\mathrm{Cr}$ were grouped together near the right side of the $\mathrm{X}$-axis (Fig. 6), which contributed positive loading to PC1. The first two PCs with eigenvalues of 4.15 and 1.33 were extracted, which accounted for $78.25 \%$ of the total variance (Table 5). The first principal component occupied $59.24 \%$ of the total variance and had high loadings of $\mathrm{Ni}$ (0.941), $\mathrm{Zn} \mathrm{(0.920),} \mathrm{Cu}$ (0.885), $\mathrm{Cr}$ (0.764), $\mathrm{Pb}(0.681)$ and $\mathrm{Cd}(0.657)$, which were the most

Table 4. Correlation coefficients among the concentrations of the heavy metals, properties and nutrient in surface sediments $(\mathrm{n}=36)$.

\begin{tabular}{|c|c|c|c|c|c|c|c|c|c|c|c|}
\hline & $\mathrm{pH}$ & $\mathrm{EC}$ & $\mathrm{TP}$ & $\mathrm{TN}$ & $\mathrm{TC}$ & $\mathrm{Cr}$ & $\mathrm{Ni}$ & $\mathrm{Cu}$ & $\mathrm{Zn}$ & $\mathrm{As}$ & $\mathrm{Cd}$ \\
\hline $\mathrm{EC}$ & $0.821^{* *}$ & 1 & & & & & & & & \\
\hline $\mathrm{TP}$ & $0.459^{* *}$ & 0.288 & 1 & & & & & & & \\
\hline $\mathrm{TN}$ & 0.310 & $0.389^{*}$ & $0.560^{* *}$ & 1 & & & & & & & \\
\hline $\mathrm{TC}$ & $0.380^{*}$ & $0.381^{*}$ & 0.138 & $0.615^{* *}$ & 1 & & & & & & \\
\hline $\mathrm{Cr}$ & $-0.510^{* *}$ & $-0.552^{* *}$ & -0.194 & $-0.549^{* *}$ & $-0.750^{* *}$ & 1 & & & & & \\
\hline $\mathrm{Ni}$ & $-0.512^{* *}$ & $-0.339^{*}$ & -0.170 & -0.287 & $-0.547^{* *}$ & $0.662^{* *}$ & 1 & & & & \\
\hline $\mathrm{Cu}$ & $-0.493^{* *}$ & -0.262 & -0.199 & -0.283 & $-0.455^{* *}$ & $0.495^{* *}$ & $0.821^{* *}$ & 1 & & & \\
\hline $\mathrm{Zn}$ & $-0.513^{* *}$ & -0.313 & -0.191 & $-0.354^{*}$ & $-0.571^{* *}$ & $0.644^{* *}$ & $0.821^{* *}$ & $0.921^{* *}$ & 1 & & \\
\hline $\mathrm{As}$ & 0.137 & 0.261 & -0.117 & 0.252 & $0.640^{* *}$ & $-0.587^{* *}$ & -0.317 & -0.116 & $-0.338^{*}$ & 1 & 1 \\
\hline $\mathrm{Cd}$ & $-0.532^{* *}$ & $-0.509^{* *}$ & -0.180 & -0.205 & $-0.361^{*}$ & $0.461^{* *}$ & $0.557^{* *}$ & $0.449^{* *}$ & $0.509^{* *}$ & -0.230 & 1 \\
\hline $\mathrm{Pb}$ & $-0.451^{* *}$ & -0.245 & -0.128 & -0.099 & -0.223 & 0.322 & $0.713^{* *}$ & $0.653^{* *}$ & $0.509^{* *}$ & 0.117 & $0.344^{*}$ \\
\hline
\end{tabular}

Notes: EC, TP, TN and TC were represented electric conductivity, total phosphor, total nitrogen and total carbon. *Correlation is significant at the 0.05 level (two-tailed), ${ }^{* *}$ Correlation is significant at the 0.01 level (two-tailed). 

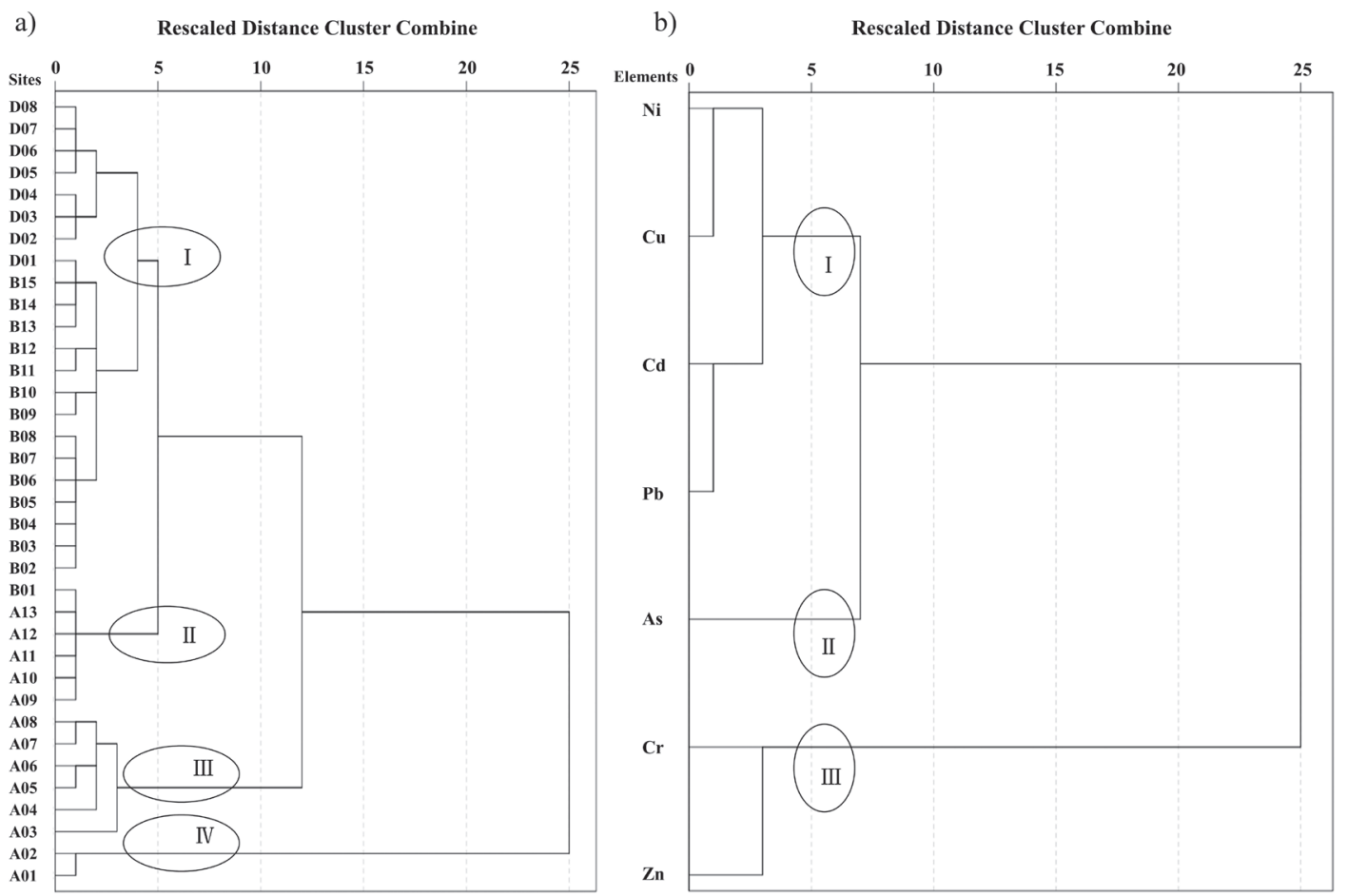

Fig. 7. Dendrogram showing the relationship between a) 36 sampling sites and b) 7 heavy metals.

important component. According to previous research, we concluded that in Ebinur Lake, $\mathrm{Cu}, \mathrm{Ni}$, and $\mathrm{Zn}$ in the sediments may mainly originate from the highly natural geological background value in the Tianshan Mountains [24]. Taken as a whole, the accumulated heavy metals $\mathrm{Ni}$ and $\mathrm{Cu}$ were mainly from industrial and agricultural activities, and $\mathrm{Zn}$ concentration was close to industrial waste gas or water discharge [49]. The second PC comprised $19.01 \%$ of the total variance and As (0.850) and $\mathrm{Pb}(0.558)$ had higher contributions, indicating that As sources were different from others.

\section{Hierarchical Cluster Analysis (HCA)}

The sample sites cluster (Fig. 7a) could be clustered into four groups obtained by HCA. The first cluster consisted of 22 sample sites including sediments with the highest concentrations of $\mathrm{Ni}, \mathrm{Zn}$ and $\mathrm{Cu}$ and intermediate values of the remaining metals, which were within the range of three quarters. The second cluster included the 6 sample sites, with the concentrations of these heavy metals within the range of typical values, with similar levels to background values. The third cluster included 6 samples sites, the concentration of $\mathrm{Cr}$ and $\mathrm{Cd}$ metals were highest, and the remaining metals were within a relatively high range. The fourth cluster of only two sample sites (B14 and B15) of Barkol Lake presented the highest concentrations of As and $\mathrm{Pb}$. Three clusters were observed for the heavy metals in sediment (Fig. 7b). The $1^{\text {st }}$ cluster formed by $\mathrm{Ni}, \mathrm{Cu}, \mathrm{Cd}$ and $\mathrm{Pb}$ was correlated with each other (Table 4). The second formed As, and the third cluster

Table 5. Total variance explained and component matrices for heavy metals concentrations.

\begin{tabular}{|c|c|c|c|c|c|c|}
\hline \multirow{2}{*}{ Component } & \multicolumn{2}{|c|}{ Eigenvalues of the Correlation Matrix } & \multirow{2}{*}{ Variables } & \multicolumn{2}{|c|}{ Component Loadings } \\
\cline { 2 - 4 } & Total & Of variance (\%) & Cumulative (\%) & & PC1 & PC2 \\
\hline 1 & 4.147 & 59.237 & 59.237 & $\mathrm{Cr}$ & 0.764 & -0.448 \\
\hline 2 & 1.331 & 19.010 & 78.247 & $\mathrm{Ni}$ & 0.941 & 0.091 \\
\hline 3 & 0.640 & 9.142 & 87.389 & $\mathrm{Cu}$ & 0.885 & 0.284 \\
\hline 4 & 0.447 & 6.388 & 93.777 & $\mathrm{Zn}$ & 0.920 & 0.012 \\
\hline 5 & 0.280 & 4.005 & 97.783 & $\mathrm{As}$ & -0.391 & 0.850 \\
\hline 6 & 0.115 & 1.640 & 99.422 & $\mathrm{Cd}$ & 0.657 & -0.079 \\
\hline 7 & 0.040 & 0.578 & 100 & $\mathrm{~Pb}$ & 0.681 & 0.558 \\
\hline
\end{tabular}


was formed by $\mathrm{Cr}$ and $\mathrm{Zn}$, indicating that heavy metals in a saline lake ecosystem have three different sources. As is usually used as a marker element of agricultural practice such as the excessive use of pesticides and herbicides [50], including calcium arsenate and lead arsenate [51]. Besides agriculture activities, the salt chemistry and mining activities in Barkol County may make relatively big contributions to the enrichment of $\mathrm{Cr}, \mathrm{Cd}, \mathrm{As}$ and $\mathrm{Pb}$ [52]. In this study the three heavy metals $\mathrm{Cr}$, As, and $\mathrm{Cd}$ lead to a high values of $E F, I_{\text {geo }}$, and in saline lake sediment. A previous study found that the heavy metals of As and $\mathrm{Cd}$ concentrations in sediments were relatively higher, which demonstrated that rapid economic and industrial increase is one of the most important reasons for heavy metal enrichment in saline lake sediments [53].

\section{Conclusions}

An overall ecological heavy metal risk in sediments was conducted in three major saline lakes in the arid region of Xinjiang, China. The average concentration of heavy metals $(\mathrm{Cr}, \mathrm{Cu}, \mathrm{Zn}, \mathrm{As}$, and $\mathrm{Cd})$ in sediments of saline lakes were higher than the background values of Xinjiang soil - in particular the mean concentrations of $\mathrm{As}$ and $\mathrm{Cd}$, which are 3.36 and 2.58 times the background values, respectively. According to the $E F$, $I_{g e o}$ and $R I$ analysis, a total of $4(11.1 \%)$ sites exhibited moderate risk and approximately $89.9 \%$ (32) of the sites presented low risk. All in all, there is a relatively low potential ecological heavy metal risk existing in the sediment of the saline lake in the arid region of Xinjiang. Based on multivariate statistical analysis, As and $\mathrm{Cd}$ were identified as the major inorganic pollutants in saline lake sediments, and As and Cd mainly came from salt chemical and agricultural sources. Important strategies should be implemented to cut down the overuse of pesticides in Ebinur basin. Also, controlling emissions from industrial sources is required to reduce ecological risks from excessive $\mathrm{Cd}$ enrichment.

The present study has demonstrated the importance understanding the ecological risk and sources of metals for lake regulation. Heavy metal toxicity depends on concentrations and fractions, and it is essential to know the bio-available concentrations of metals and the sensitivities of local benthic communities. Thus, more studies are needed to better research the fractions of metals. Some research has demonstrated that antimony (Sb) and wolfram (W) have been significantly accumulating, and elevated concentrations have been observed in surface sediments in Poyang and Dongting lakes [54]. Sb and $\mathrm{W}$ are hazardous to human health or pose ecological risks to the benthic community [55]. In addition to these 7 heavy metals, $\mathrm{Sb}$ and $\mathrm{W}$ and other metalloid elements should be of more concern to investigators.

\section{Acknowledgements}

The authors would like to thank the Ebinur National Wetland Nature Reserve. We are grateful to Prof. Wenwei Gao for his help in field sampling. This research was supported by the National Natural Science Foundation of China (Nos. 31560171 and 41877109), the Graduate Student Innovation Program of Xinjiang Agricultural University (No. XJAUGR2018011), and the Thousand Young Talents Program, Chinese Academy of Sciences (No. Y772121).

\section{Conflict of Interest}

The authors declare no conflict of interest.

\section{References}

1. YANG J.M., MA L., LI C.Z., LIU Y., DING J., YANG S. Temporal-spatial variations and influencing factors of lakes in inland arid areas from 2000 to 2017: a case study in Xinjiang. Geomat. Nat. Haz .Risk. 10 (1), 519, 2019.

2. LI X., YANG H., ZHAN C., ZENG G., LIU Y., XU W., WU Y., LAN S. Spatial distribution and transport characteristics of heavy metals around an antimony mine area in central China. Chemosphere. 170, 17, 2017.

3. HAKANSON L. Sediment variability. In: Burton GA Jr. Sediment toxicity assessment. Lewis Publishers: Boca Raton; 19, USA, 1992.

4. DING Z.H., LIU J.L, LI L.Q., LIN H.N., WU H., HU Z.Z. Distribution and speciation of mercury in surficial sediments from main mangrove wetlands in China. Mar. Pollut. Bull. 58 (9), 1319, 2009.

5. SANTOSH K.S. Trace metals in a tropical mangrove wetland. Springer-Verlag; 1-216, Singapore, 2018.

6. GAO X.Y., LI J., WANG X.N., ZHOU J.L., FAN B., LI W.W., LIU Z.T. Exposure and ecological risk of phthalate esters in the Taihu Lake basin, China. Ecotox. Environ. Safe. 171, 564, 2019.

7. GU Y.G., LIN Q., JIANG S.J., WANG Z.H. Metal pollution status in Zhelin Bay surface sediments inferred from a sequential extraction technique, South China Sea. Mar Pollut Bull. 81 (1), 256, 2014.

8. CAMARGO J.B.D.A., CRUZ A.C.F., CAMPOS B.G., ARAU'JO G.S., FONSECA T.G., ABESSA D.M.S. Use development and improvements in the protocol of whole sediment toxicity identification evaluation using benthic copepods. Mar. Pollut. Bull. 91 (2), 511, 2015.

9. ZAHRA A., HASHMI M.Z., MALIK R.N., AHMED Z. Enrichment and geoaccumulation of metals and risk assessment of sediments of the Kurang Nallah - feeding tributary of the Rawal Lake reservoir, Pakistan. Sci. Total Environ. 470-471 (2), 925, 2014.

10. ZHANG Z.Y., JUYING L., MAMAT Z., QINFU $Y$. Sources identification and pollution evaluation of heavy metals in the surface sediments of Bortala River, Northwest China. Ecotox. Environ. Safe. 126, 94, 2016.

11. LIN Q., LIU E.F., ZHANG E.L., LI K., SHEN J. Spatial distribution, contamination and ecological risk assessment of heavy metals in surface sediments of Erhai Lake, a large eutrophic plateau lake in southwest China. Catena. 145, 193, 2016. 
12. XIE Z., JIANG Y., ZHANG H., WANG D., QI S., DU Z., ZHANG $\mathrm{H}$. Assessing heavy metal contamination and ecological risk in Poyang Lake area, China. Environ. Earth Sci. 75 (7), 549, 2016.

13. JIANG X., WANG W., WANG S., ZHANG B., HU J. Initial identification of heavy metals contamination in Taihu Lake, a eutrophic lake in China. J. Environ. Sci. 24 (9), 1539, 2012.

14. GUO H.J., YANG L.Y., HAN X.M., DAI J.R., PANG X.G., REN M.Y., ZHANG W. Distribution characteristics of heavy metals in surface soils from the western area of Nansi Lake, China. Environ. Monit. Assess. 191 (5), 262, 2019.

15. ZENG H., WU J., LIU W. Two-century sedimentary record of heavy metal pollution from Lake Sayram: a deep mountain lake in central Tianshan, China. Quat. Int. 321, 125, 2014.

16. KUANG S., BAO Q.B., KANG D.J., SHEN Q.S., ZHANG L., LIU CH., WANG K. Distribution patterns and ecological risk assessment of heavy metal contamination in surface sediments deposited in a typical small sized water reservoir. J. Lake. Sci. 30 (2), 336, 2018 [In Chinese].

17. BING H.J., WU Y.H., ZHOU J., SUN H.Y., WANG X.X., ZHU H. Spatial variation of heavy metal contamination in the riparian sediments after two-year flow regulation in the three gorges reservoir, China. Sci. Total. Environ. 649, 1004, 2019.

18. KARN S.K. Arsenic (As) contamination: a major risk factor in Xinjiang Uyghur autonomous region of China. Environ. Pollut. 207, 434, 2015.

19. ZHOU Y., ZENG Y., ZHOU J., GUO H., LI Q., JIA R., CHEN Y., ZHAO J. Distribution of groundwater As in Xinjiang, P.R. China. Appl. Geochem. 77, 116, 2017.

20. ZHANG J.Y., YU F., PANG S.D., YU Y.C. Spatial distribution and pollution assessment of potentially toxic elements in urban forest soil of Nanjing, China. Pol. J. Environ. Stud. 28 (4), 3015, 2019.

21. JIN X.Y., FAN J.S., NIU H.Y., LING P., YU Q.Q. Analysis of sources and concentrations of heavy metal contents in $\mathrm{PM}_{10}$ over a four-season cycle in a heavily industrialized city in China. Pol. J. Environ. Stud. 28 (5), 3227, 2019.

22. HU B.F., JIA X.L., HU J., XU D.Y., XIA F., LI Y. Assessment of heavy metal pollution and health risks in the soil-plant-human system in the Yangtze River Delta, China. Int. J. Environ. Res. Public Health. 14 (9), 1042, 2017.

23. WANG W., LAI Y., MA Y., LIU Z., WANG S., HONG C. Heavy metal contamination of urban topsoil in a petrochemical industrial city in Xinjiang, China. J. Arid Land. 8 (6), 871, 2016.

24. ZHANG Z.Y., ABUDUWAIL J., JIANG F. Q. Heavy metal contamination, sources, and pollution assessment of surface water in the Tianshan Mountains of China. Environ. Monit. Assess. 187 (2), 33, 2015.

25. ABUDUWAILIL J., ZHANG Z.Y., JIANG F.Q. Evaluation of the pollution and human health risks posed by heavy metals in the atmospheric dust in Ebinur Basin in Northwest China. Environ. Sci. Pollut. Res. 22 (18), 14018, 2015.

26. MAMAT Z., HAXIMU S., ZHANG Z.Y., AJI R. An ecological risk assessment of heavy metal contamination in the surface sediments of Bosten Lake, Northwest China. Environ. Sci. Pollut. R. 23 (8), 7255, 2016.

27. MA R.H., YANG G.H., DUAN H.T., JIANG J.H., WANG S.M., FENG X.Z., LI A.N., KONG F.X., XUE B., WU J.L.,
LI S.J. China's lakes at present, Number, area and spatial distribution. Sci. China Earth Sci. 54 (3), 394, 2011.

28. YANG Y., JIN Q., FANG J., LIU F., LI A., TANDON P., SHAN A. Spatial distribution, ecological risk assessment, and potential sources of heavy metal(loid)s in surface sediments from the Huai River within the Bengbu section, China. Environ. Sci. Pollut. R. 24 (12), 11360, 2017.

29. CHAI L., LI H., YANG Z., MIN X., LIAO Q., LIU Y., MEN S. H., YAN Y., XU J. Heavy metals and metalloids in the surface sediments of the Xiangjiang River, Hunan, China: distribution, contamination, and ecological risk assessment. Environ. Sci. Pollut. Res. 24 (1), 874, 2017.

30. MATEJOVIC I. Determination of carbon and nitrogen in samples of various soils by the dry combustion. Commun. Soil Sci. Plant Anal. 28 (17-18), 1499, 1997.

31. SPARKS D.L., PAGE A., HELMKE P., LOEPPERT R., SOLTANPOUR P., TABATABAI M., JOHNSTON C., SUMNER M. Methods of soil analysis. Part 3 Chemical methods. Soil Science Society of America Inc, 769, 1996.

32. BAO S.D. Soil analysis for agronomy, third ed. China Agriculture Press; 32, Beijing, 2000 [In Chinese].

33. WANG H., WANG J., LIU R., YU W., SHEN Z. Spatial variation, environmental risk and biological hazard assessment of metals in surface sediments of the Yangtze River estuary. Mar. Pollut. Bull. 93 (1-2), 250, 2015.

34. LEE D.S., GARLAND J.A., FOX A.A. Atmospheric concentrations of trace elements in urban areas of the United Kingdom. Atmos. Environ. 28 (16), 2691, 1994.

35. WEI F.S., CHEN J.S., WU Y.Y. Background values of soil elements in China. China Environmental Science Press; 1, Beijing, 1990 [In Chinese].

36. LIU C.W., LIN K.H., KUO Y.M. Application of factor analysis in the assessment of groundwater quality in a Blackfoot disease area in Taiwan. Sci. Total. Environ. 313 (1-3), 77, 2003.

37. MÜLLER G. Index of geoaccumulation in sediments of the Rhine River. Geo-journal. 2, 108, 1969.

38. YANG X.R., ZHANG X.F., WU Z.Y., ZHAO X.S., CHAI F.M., SUN B.S., CHEN C. Element geochemistry characteristics of the supera-crust, Xinjiang, China. Arid Land Geography. 32 (3), 340, 2009 [In Chinese]

39. CHRISTOPHORIDIS C., DEDEPSIDIS D., FYTIANOS $\mathrm{H}$. Occurrence and distribution of selected heavy metals in the surface sediments of Thermaikos Gulf, N. Greece. Assessment using pollution indicators. J. Hazard. Mater. 168 (2-3), 1082, 2009.

40. BHUIYAN M.A.H., PARVEZ L., ISLAM M.A., DAMPARE S.B., SUZUKI S. Heavy metal pollution of coal mine-affected agricultural soils in the northern part of Bangladesh. J. Hazard. Mater. 173 (1-3), 384, 2010.

41. HAKANSON L. An ecological risk index for aquatic pollution control: a sediment ecological approach. Water Res. 14 (8), 975, 1980.

42. ZAHARESCU D.G., HOOD P.S., SOLER A.P., FERNANDEZ J., BURGHELEA C.I. Trace metals and their source in the catchment of the high altitude Lake Respomuso, Central Pyrenees. Sci. Total Environ. 407 (11), 3546, 2009.

43. DAMLE T., KSHIRSAGAR M. Role of permutations in significance analysis of microarray and clustering of significant microarray gene list. International Journal of Computer Science Issues. 9 (2), 342, 2012.

44. LIU Y., MA Z., LV J., BI J. Identifying sources and hazardous risks of heavy metals in topsoils of rapidly urbanizing East China. J. Geog. Sci. 26 (6), 735, 2016. 
45. ISLAM M.S., AHMED M.K., RAKNUZZAMAN M., HABIBULLAH-AL-MAMUN M., ISLAM M.K. Heavy metal pollution in surface water and sediment, a preliminary assessment of an urban river in a developing country. Ecol. Indic. 48, 282, 2015.

46. IOANNIDES K., STAMOULIS K., PAPACHRISTODOULOU C., TZIAMOU E., MARKANTONAKI C., TSODOULOS I. Distribution of heavy metals in sediment cores of Lake Pamvotis (Greece): a pollution and potential risk assessment. Environ. Moni. Assess. 187 (1), 4209, 2015.

47. ZHANG Y., SHI T., ZHANG Y., YU T. Spatial distribution and risk assessment of heavy metals in sediments from a hypertrophic plateau lake Dianchi, China. Environ. Monit. Assess. 186 (2), 1219, 2014.

48. ABRAHIM G.M.S., PARKER R.J. Assessment of heavy metal enrichment factors and the degree of contamination in marine sediments from Tamaki Estuary, Auckland, New Zealand. Environ. Monit. Assess. 136 (1-3), 227, 2008.

49. FACCHINELLI A., SACCHI E., MALLEN L. Multivariate statistical and GIS-based approach to identify heavy metal sources in soils. Environ. Pollut. 114 (3), 313, 2001.

50. MICO' C., RECATALA' L., PERI'S M., SA'NCHEZ J. Assessing heavy metal sources in agricultural soils of a European Mediterranean area by multivariate analysis Chemosphere. 65 (5), 863, 2006.

51. XU Y., SUN Q., YI L., YIN X., WANG A., LI Y., CHEN J. The source of natural and anthropogenic heavy metals in the sediments of the Minjiang River estuary (SE China): implications for historical pollution. Sci. Total Environ. 493, 729, 2014.

52. YU Z.L. New strides have been made in the economic and social development of Barkol County. Tribun of Social Sciences in Xinjiang. S1, 18, 2003 [In Chinese].

53. MI Y., CHANG S. L., SHI Q. D., GAO X., HUANG C. Study on the effect of agricultural non-point source pollution to water environment of the Ebinur Lake Basin during high flow period. Arid Zone Research. 27 (2), 278, 2010 [In Chinese].

54. TIAN H.Z., ZHAO D., HE M.C., WANG Y., CHENG K. Temporal and spatial distribution of atmospheric antimony emission inventories from coal combustion in China. Environ. Pollut. 159 (6), 1613, 2011.

55. HAMMEL W., DEBUS R., STEUBING L. Mobility of antimony in soil and its availability to plants. Chemosphere. 41 (11), 1791, 2000. 